Southern Illinois University Carbondale

OpenSIUC

Publications

Fisheries and Illinois Aquaculture Center

$10-2015$

\title{
Recruitment Sources of Invasive Bighead Carp (Hypopthalmichthys nobilis) and Silver Carp (H. molitrix) Inhabiting the Illinois River
}

Jacob D. Norman

Gregory Whitledge

Southern Illinois University Carbondale, gwhit@siu.edu

Follow this and additional works at: http://opensiuc.lib.siu.edu/fiaq pubs

The final publication is available at Springer via http://dx.doi.org/10.1007/s10530-015-0929-9

\section{Recommended Citation}

Norman, Jacob D. and Whitledge, Gregory. "Recruitment Sources of Invasive Bighead Carp (Hypopthalmichthys nobilis) and Silver Carp (H. molitrix) Inhabiting the Illinois River." Biological Invasions 17, No. 10 (Oct 2015): 2999-3014. doi:10.1007/ s10530-015-0929-9. 
Recruitment sources of invasive Bighead Carp (Hypopthalmichthys nobilis) and Silver Carp (H. molitrix) inhabiting the Illinois River

Jacob D. Norman ${ }^{1}$ and Gregory W. Whitledge* Center for Fisheries, Aquaculture, and Aquatic Sciences, Southern Illinois University, 1125 Lincoln Drive, Carbondale, IL 62901-6511 USA

*Corresponding author. e-mail: gwhit@ siu.edu; phone: (618) 453-6089; FAX: (618) 453-6095

${ }^{1}$ Present address: Texas Parks and Wildlife Department, Inland Fisheries, 11810 FM 848, Tyler, TX 75707 USA

Key Words:

Asian Carp, natal environment, stable isotopes, microchemistry, $\delta^{18} \mathrm{O}, \mathrm{Sr}: \mathrm{Ca}$, otoliths 


\begin{abstract}
Knowledge of natal environments and dispersal of invasive Bighead Carp (Hypopthalmichthys nobilis) and Silver Carp (H. molitrix) inhabiting the Illinois River would be valuable for directing population reduction efforts intended to supplement electrical barriers in the Chicago Sanitary and Ship Canal and limit the probability of these species invading the Great Lakes. However, the extent to which Bighead Carp and Silver Carp (collectively referred to as bigheaded carps) stocks in the Illinois River are derived from recruits that originate within the Illinois River itself versus immigrants from the Mississippi and Missouri rivers is unknown. Bigheaded carps are also known to use connected floodplain lakes during early life, but the contribution of these habitats to recruitment of Bighead and Silver carps in the Illinois River is also unknown. The aim of this study was to identify natal environment of adult bigheaded carps collected from the Illinois River during 2010-2011 using stable isotope and trace element analyses of otolith cores. Both water and otolith strontium:calcium ratios (Sr:Ca) and water and otolith oxygen isotope ratios (expressed as $\delta^{18} \mathrm{O}$ ) were strongly correlated for known-origin bigheaded carps, consistent with other fish species. Most Bighead and Silver carps collected from the Illinois River used river channel rather than floodplain lake habitats during early life. The majority of adult Silver Carp originated in the Illinois River, although 11-39\% were immigrants from the Missouri or middle Mississippi rivers. In contrast, 97\% of the Bighead Carp originated in the Illinois River. Our results indicate that efforts to substantially reduce abundance of bigheaded carps in the Illinois River drainage should continue to focus on the Illinois River itself, but will likely need to be expanded to include the middle Mississippi and Missouri Rivers for sustainable control of Silver Carp.
\end{abstract}




\section{Introduction}

Invasive species are one of the primary factors responsible for the imperiled status of many native freshwater species (Jelks et al. 2008), and escalating rates of biological invasions in freshwater ecosystems are predicted to result in increasingly adverse ecological and economic effects (Sala et al. 2000; Lodge et al. 2006). Two invasive fish species of particular concern are the Bighead Carp (Hypophthalmichthys nobilis) and Silver Carp (H. molitrix), collectively known as bigheaded carps. These two species are highly efficient filter feeders introduced into the United States during the early 1970s to control algae in aquaculture and wastewater treatment ponds (Kelly et al. 2011). Both species subsequently escaped confinement and established naturally reproducing populations in the Mississippi, Ohio, Missouri, and Illinois rivers (Chick and Pegg 2001). Abundance and biomass of Bighead and Silver carps have increased exponentially in the Illinois River (Sass et al. 2010; Irons et al. 2011); available evidence indicates that competition resulting from similar diet composition among bigheaded carps and native filter-feeding fishes (Sampson et al. 2009) may negatively affect growth and condition of the native species (Schrank et al. 2003; Irons et al. 2007). The high densities of Bighead and Silver carps in the Illinois River and their capacity for rapid, long-distance movement (Peters et al. 2006; DeGrandchamp et al. 2008) have led to concerns regarding these species invading the Great Lakes via the artificial Chicago-area waterways that link the Illinois River drainage with Lake Michigan, with potentially serious consequences for Great Lakes food webs and the economically important recreational and commercial fisheries they support (Kolar and Lodge 2002; Cudmore and Mandrak 2011). 
Electric barriers installed in the Chicago Sanitary and Ship Canal (Moy et al. 2011) currently represent the primary line of defense for limiting the potential of bigheaded carps to invade Lake Michigan from the Illinois River watershed. However, electric barriers may not be 100\% effective for deterring Bighead and Silver carps; environmental DNA from these species has been detected in the Chicago waterways above the barriers and in Lake Michigan (Jerde et al. 2011; Mahon et al. 2011), and a live Bighead Carp was captured from Lake Calumet (on the Lake Michigan side of the barriers) in June 2010. As a supplemental control measure, the state of Illinois recently implemented an enhanced commercial harvest program intended to reduce bigheaded carp abundance in the Illinois River, with the primary goal of minimizing propagule pressure on the electric barriers (Garvey et al. 2012). However, enhanced commercial harvest is currently limited to the Illinois River and does not extend to the Mississippi or lower Missouri rivers. Thus, substantial immigration of Bighead Carp or Silver Carp from either of these two rivers could reduce sustainability and efficiency of control efforts within the Illinois River. Limited knowledge of recruitment dynamics of Bighead and Silver carps in the Mississippi River basin, including river segments that represent the principal recruitment sources for these species, is an important source of uncertainty in predicting population responses to fishing and development of spatially explicit harvest and other potential control strategies (Tsehaye et al. 2013).

Bighead Carp and Silver Carp in the Illinois River may include individuals that originated in the Illinois River itself as well as immigrants from the Mississippi and Missouri rivers. However, the relative importance of the Illinois, Mississippi, and Missouri rivers as natal environments and recruitment sources for Illinois River bigheaded carp stocks is unknown. As of 2013, bigheaded carps were known to be reproducing in the middle and lower sections of the 
Illinois River, the Mississippi River downstream from the mouth of the Missouri River, the lower Missouri River (unimpounded section), and pools 22, 24, and 26 of the upper Mississippi River (impounded section of the river upstream from the Missouri River confluence) (Schrank et al. 2001; DeGrandchamp et al. 2007; Lohmeyer and Garvey 2009; Baerwaldt et al. 2013; Deters et al. 2013). In the Mississippi River, larval bigheaded carp densities were substantially higher in pool 26 and the open river downstream from the Missouri River confluence compared to pools 22 and 24 (Lohmeyer and Garvey 2009). Age-0 bigheaded carps have also been collected from connected floodplain lakes along the Illinois River (Pegg et al. 2002; DeGrandchamp et al. 2007); however, the relative importance of these floodplain lakes and low-velocity river channel margin habitats as nursery areas for Bighead and Silver carps is also unknown. A recently developed simulation model indicated that harvesting all sizes of Bighead and Silver carps is required to achieve fishery-induced collapse (Tsehaye et al. 2013). Thus, improved understanding of natal environments and early life habitat use of Bighead and Silver carps is particularly important to determine the appropriate spatial scale for enhanced commercial harvest and other control measures and to direct such efforts to areas that contribute substantially to recruitment of these species.

Trace element and stable isotopic compositions of otoliths have been used as natural markers of environmental history for individual fishes in a variety of freshwater environments (Wells et al. 2003; Dufour et al. 2005; Munro et al. 2005; Whitledge et al. 2007; Zeigler and Whitledge 2010, 2011; Chapman et al. 2013), and represent a potential approach to identify natal environment and larval and juvenile nursery habitats of Bighead Carp and Silver Carp in the Illinois River. Otoliths are calcareous concretions in the inner ear of fishes that contain a permanent record of age and growth and are metabolically inert (Campana and Thorrold 2001). 
Otolith strontium:calcium ( $\mathrm{Sr}: \mathrm{Ca}$ ) ratios and stable oxygen isotopic compositions are strongly correlated with those of the environment occupied by a fish (Wells et al. 2003; Zeigler and Whitledge 2010; Smith and Whitledge 2011). Stable oxygen isotope ratios $\left(\delta^{18} \mathrm{O}\right)$ of otoliths are influenced by water temperature in addition to water $\delta^{18} \mathrm{O}$ (Patterson et al. 1993). Association of otolith biochronology with isotopic or elemental composition enables retrospective description of fish environmental history (e.g., identification of natal environment from the portion of the otolith accreted during early life) when an individual has resided in chemically distinct locations for a period of time sufficient to incorporate the signature of those sites (Kennedy et al. 2002; Dufour et al. 2005; Whitledge et al. 2007). Only a few published studies have used otolith chemistry to identify natal environment of invasive fishes in large floodplain river systems. Crook et al. (2013) and Crook and Gillanders (2006) demonstrated the applicability of otolith microchemistry for identifying recruitment sources of invasive Common Carp (Cyprinus carpio) in two Australian rivers. Shen and Gao (2012) concluded that stable oxygen and carbon isotopic compositions of otoliths could be used to identify natal environment and assess stock structure of Silver Carp in a portion of the middle Yangtze River basin. The Illinois, Mississippi, and Missouri rivers possess distinct multivariate chemical signatures that can be used to identify natal environment and reconstruct inter-river movement patterns of fishes (Zeigler and Whitledge 2011; Phelps et al. 2012). Differences in stable oxygen isotope ratios between the Illinois River and its floodplain lakes also enable identification of fish use of floodplain lake habitats (Zeigler and Whitledge 2010). Thus, otolith chemistry should be applicable for identifying recruitment sources of Bighead Carp and Silver Carp in the Illinois River.

The goal of this study was to determine the principle natal environments and age- 0 nursery habitats for invasive Bighead Carp and Silver Carp in the Illinois River. Initial 
objectives were to verify that previously reported differences in water $\mathrm{Sr}: \mathrm{Ca}$ and $\delta^{18} \mathrm{O}$ among the Illinois, Missouri, and Mississippi Rivers and floodplain lakes (Zeigler and Whitledge 2010, 2011; Smith and Whitledge 2011; Phelps et al. 2012) persisted across years and to characterize relationships between water and otolith $\mathrm{Sr}: \mathrm{Ca}$ and $\delta^{18} \mathrm{O}$ for bigheaded carps. Water $\mathrm{Sr}: \mathrm{Ca}$ and $\delta^{18} \mathrm{O}$ data and relationships between water and otolith $\mathrm{Sr}: \mathrm{Ca}$ and $\delta^{18} \mathrm{O}$ were used to develop classification models to identify natal river (Missouri River, Mississippi River, or Illinois River) and age-0 nursery habitat (floodplain lake or river) of individual Bighead Carp and Silver Carp collected from three reaches of the Illinois River based on $\mathrm{Sr}: \mathrm{Ca}$ and $\delta^{18} \mathrm{O}$ values of their otolith cores (the portion of the otolith reflective of early life history). Relative abundances of Illinois River origin and immigrant (Mississippi or Missouri river origin) Bighead Carp and Silver Carp were estimated, along with the proportions of Bighead Carp and Silver Carp that used floodplain lakes as nursery areas during their first year of life.

\section{Materials and methods}

Study area

The Illinois River is formed by the confluence of the Des Plaines and Kankakee Rivers and flows westward $68 \mathrm{~km}$ before turning and flowing generally southwesterly for $372 \mathrm{~km}$ to its confluence with the Mississippi River (Koel and Sparks 2002; Fig. 1). The Illinois River watershed is connected with Lake Michigan via the Chicago Sanitary and Ship Canal, which flows into the Des Plaines River. The upper portion of the Illinois River (upstream of its turn to the southwest) is characterized by a higher gradient $(20 \mathrm{~cm} / \mathrm{km})$ and narrower channel with less floodplain habitat compared to downstream reaches, while middle and lower sections of the river have a much lower gradient $(2 \mathrm{~cm} / \mathrm{km})$ and a broad floodplain $(2.5-5 \mathrm{~km}$ wide) that still contains a portion of the complex backwater and floodplain lake habitats that were historically present, 
although many of these habitats are now isolated from the main channel by levees during normal flows (Koel and Sparks 2002). Sampling for this project was conducted in three reaches of the Illinois River (Alton, Peoria-LaGrange, and upper river; Fig. 1). The Alton reach extends from the confluence of the Illinois River and Mississippi River at Grafton, IL upstream to the LaGrange Lock and Dam. The Peoria-LaGrange reach encompasses the middle portion of the river from the LaGrange Lock and Dam upstream to the Starved Rock Lock and Dam. The upper river reach extends from the Starved Rock Lock and Dam upstream to the origin of the Illinois River at the confluence of the Des Plaines and Kankakee rivers.

\section{Water sampling}

Water samples were collected during June, August, and October 2010 and 2011 from multiple locations along the Illinois River and its floodplain lakes, the upper Mississippi River (upstream of the Missouri River confluence), middle Mississippi River (the section of the river bordering Illinois downstream of the Missouri River confluence), and Missouri River (Fig. 1). Water samples were used to monitor temporal variation in water $\mathrm{Sr}: \mathrm{Ca}$ and $\delta^{18} \mathrm{O}$ of potential natal environments for bigheaded carps present in the Illinois River and verify that spatial differences in water $\mathrm{Sr}: \mathrm{Ca}$ and $\delta^{18} \mathrm{O}$ among these locations during 2006-2009 were still present (Zeigler and Whitledge 2010, 2011; Smith and Whitledge 2011; Myers et al. 2012; Phelps et al. 2012). Sampling along the Illinois River included one main channel location each within the upper river, Peoria-LaGrange and Alton reaches and four connected floodplain lakes. Floodplain lakes sampled included Chautauqua, Anderson, and Chain lakes (Peoria-LaGrange reach) and Swan Lake (Alton reach). Water samples were also collected from the upper Mississippi River (pool 25, upstream of the Illinois River mouth), the middle Mississippi River at Chester, IL 
(downstream of the mouth of the Missouri River) and the Missouri River at St. Charles, MO. Two water samples were collected from each location on each collection date to assess temporal changes in stable isotopic and elemental compositions within and among rivers and floodplain lakes. One sample was used for stable oxygen isotope analysis and the second sample was analyzed for Sr:Ca. Samples for stable oxygen isotope analysis were collected in 20-ml scintillation vials containing minimal air space and sealed with Parafilm ${ }^{\circledR}$ to curtail evaporative loss and fractionation (Kendall and Caldwell 1998). Samples were analyzed for stable oxygen isotopic composition using a high-temperature conversion elemental analyzer (TC/EA) interfaced with a Thermo Finnigan Delta $\mathrm{V}^{\circledR}$ isotope ratio mass spectrometer at the Southern Illinois University Mass Spectrometry Facility. All stable isotope ratios were expressed in standard delta notation, defined as the parts per thousand deviation between the isotope ratio of a sample and standard material (Vienna Standard Mean Ocean Water for water $\delta^{18} \mathrm{O}$ ):

$$
\delta^{18} \mathrm{O}(\%)=[(\text { Rsample } / \text { Rstandard })-1] \times 1000 ;
$$

where R represents ${ }^{18} \mathrm{O} /{ }^{16} \mathrm{O}$. Analytical precision estimated from analysis of laboratory standards was $0.18 \%$. Water samples for analysis of strontium and calcium concentrations were collected using a syringe filtration ( $0.45 \mu \mathrm{m}$ pore size) technique described in Shiller (2003) and stored on ice or refrigerated prior to analysis. Strontium and calcium concentrations were determined using a Thermo Finnigan Element $2^{\circledR}$ high-resolution, inductively coupled plasma mass spectrometer (HR-ICPMS) at the Center for Trace Analysis, University of Southern Mississippi following standard methods (Shiller 2003). Water strontium and calcium concentration data were converted to molar Sr:Ca ratios (mmol/mol).

Fish sampling 
Adult Bighead Carp and Silver Carp (335-1170 mm total length) were collected from each of the three reaches of the Illinois River during late summer and fall (August-October) 2010 and during spring and summer (May-July) 2011. A minimum of 50 adult individuals of each species were collected from each of the three river reaches. Samples were collected with a tandem effort of boat-mounted AC electrofishing and experimental trammel nets. Trammel nets (35.56-cm bar outer mesh, 7.62-cm bar inner mesh) were deployed prior to electrofishing in attempts to drive fish into the nets. Previous studies have found electrofishing to be among the most effective sampling methods to collect Silver Carp (Williamson and Garvey 2005), while trammel netting appears to be among the best methods for sampling Bighead Carp (Garvey et al. 2012).

To characterize relationships between water and otolith $\mathrm{Sr}: \mathrm{Ca}$ and $\delta^{18} \mathrm{O}$ for bigheaded carps, we obtained Bighead Carp and Silver Carp whose recent environmental history was known from eight locations that encompassed a range of water $\mathrm{Sr}: \mathrm{Ca}$ and $\delta^{18} \mathrm{O}$ signatures. Fish sampled included adult Bighead and Silver carps that were isolated in ponds lacking inlets or outlets or in disconnected floodplain lakes for at least 18 months prior to capture. We also obtained young-of-year (YOY; i.e., age-0) Silver and Bighead carps (75-100 mm total length) that were isolated in disconnected floodplain lakes and from the upper Mississippi and lower Missouri rivers. Age-0 fishes from these two river reaches were collected from locations in which water $\mathrm{Sr}: \mathrm{Ca}$ and $\delta^{18} \mathrm{O}$ were consistent for $>120 \mathrm{~km}$ upstream or downstream from collection locations; thus, otolith edge $\mathrm{Sr}: \mathrm{Ca}$ and $\delta^{18} \mathrm{O}$ for these fish would likely reflect that of the river reaches in which they were collected. Water samples were collected from each river or pond at the time of fish collection and analyzed for $\mathrm{Sr}: \mathrm{Ca}$ and $\delta^{18} \mathrm{O}$ using procedures described previously for river water samples. 
Otolith stable isotope and elemental analyses

Both lapilli otoliths were removed from each fish with non-metallic forceps, rinsed in distilled water, and stored dry in microcentrifuge tubes until preparation for stable isotope and elemental analyses. Lapilli were used rather than asterisci otoliths because the asterisci possess a vaterite crystalline structure (as opposed to aragonite in lapilli); aragonite has a higher affinity for strontium than vaterite (Melancon et al. 2005) and, therefore, the lapilli were preferable for analysis of otolith Sr:Ca in Bighead and Silver carps. Equivalent differences in calcium carbonate crystalline structure between lapilli and asterisci have also been observed in Grass Carp Ctenopharyngodon idella (Chapman et al. 2013).

One otolith from each fish was used for stable oxygen isotope analysis. Whole otoliths from YOY fish were pulverized with a mortar and pestle to produce a fine powder for analysis. Otoliths from adult fish were embedded in Epo-fix epoxy (Electron Microscopy Sciences Inc., Hatfield, PA), sectioned in the transverse plane using an ISOMET low-speed saw, sanded (400, $500,600,800$, and 1000 grit in sequence) to achieve a 1.2-mm section centered on the otolith nucleus, and polished with lapping film. Sectioned otoliths were affixed to glass microscope slides using cyanoacrylate glue. A 300- $\mu$ g subsample of $\mathrm{CaCO}_{3}$ was obtained from the otolith core (within the first annulus, centered on the nucleus) for each adult fish collected from the Illinois River (fish of unknown origin) using a New Wave Research micromill. Resolution of stable carbon and oxygen isotope analysis using this procedure corresponded to approximately the first growing season of a fish's life based on mean otolith mass ( $273 \mu \mathrm{g} \pm 9 \mu \mathrm{g}$ SE) of age- 0 Silver Carp (85-90 mm total length) collected during October 2008. For each adult fish of known recent environmental history collected from isolated ponds or disconnected floodplain 
lakes, a 300- $\mu$ g subsample was obtained from the outer edge of the otolith to characterize the relationship between water and otolith $\delta^{18} \mathrm{O}$ for bigheaded carps. Stable oxygen isotope analysis of otolith subsamples was conducted using a ThermoFinnigan Delta $\mathrm{V}^{\circledR}$ isotope ratio mass spectrometer interfaced with a Gas Bench $\mathrm{II}^{\circledR}$ carbonate analyzer. All measurements are reported in standard delta notation $\left(\delta^{18} \mathrm{O}, \%\right)$ relative to the Vienna Pee Dee Belemnite standard. Analytical precision estimated from analysis of laboratory standards was $0.10 \%$ for $\delta^{18} \mathrm{O}$.

The second lapilli otolith from each fish was used for analysis of Sr:Ca. Otoliths were embedded in Epo-fix ${ }^{\circledR}$ epoxy and sectioned in the transverse plane to a thickness of $0.7 \mathrm{~mm}$ centered around the otolith nucleus using an ISOMET low-speed saw. Otolith sections were sanded using silicon carbide sandpaper (400,500, 600, 800, and 1000 grit in sequence) and polished with lapping film to expose the otolith core. Polished sections were mounted on acidwashed glass microscope slides using double-sided tape, ultrasonically cleaned for $5 \mathrm{~min}$ in ultrapure water, and dried for $24 \mathrm{~h}$ under a class 100 laminar flow hood. Samples were stored in acid-washed polypropylene Petri dishes in a sealed container until analysis. Sectioned otoliths were analyzed for strontium and calcium concentrations using a Perkin-Elmer DRC II inductively coupled plasma mass spectrometer (ICPMS) coupled with a CETAC Technologies LSX-500 laser ablation system. The laser ablated a transect extending from one side of the otolith core to the edge of the opposite side of the otolith along the longest axis of the section (beam diameter $=25 \mu \mathrm{m}$, scan rate $=5 \mu \mathrm{m} / \mathrm{s}$, laser pulse rate $=20 \mathrm{~Hz}$, laser energy level $=75 \%$, wavelength $=266 \mathrm{~nm}$ ). Otolith core (first $100 \mu \mathrm{m}$ of the laser transect) Sr:Ca was used to identify natal environment for individual fish; mean otolith radius for age-0 fish $(85-90 \mathrm{~mm}$ total length) collected during October 2008 was $327 \mu \mathrm{m} \pm 14 \mu \mathrm{m}$ SE.. A standard developed by the U.S. Geological Survey (MACS-1; $\mathrm{CaCO}_{3}$ matrix) was analyzed every 12-15 samples to enable 
quantification and correction of possible instrumental drift. Each sample analysis was preceded by a $30 \mathrm{~s}$ gas blank measurement. Isotopes assayed included ${ }^{43} \mathrm{Ca},{ }^{44} \mathrm{Ca},{ }^{46} \mathrm{Ca},{ }^{86} \mathrm{Sr}$, and ${ }^{88} \mathrm{Sr}$. Isotopic counts were converted to elemental concentrations $(\mu \mathrm{g} / \mathrm{g})$ after correction for gas blank, matrix, and drift effects (Ludsin et al. 2006). Strontium concentration was normalized to calcium concentration based on the consideration of calcium as an internal standard and the stoichiometric concentration of calcium in aragonite (Chapman et al. 2013). Otolith microchemistry data are reported as $\mathrm{Sr}: \mathrm{Ca} \operatorname{ratios}(\mu \mathrm{mol} / \mathrm{mol})$.

Data analyses

Nested two-way ANOVAs followed by Tukey's HSD test for multiple comparisons were conducted to assess differences in water mean $\mathrm{Sr}: \mathrm{Ca}$ and $\delta^{18} \mathrm{O}$ among rivers and floodplain lakes in our study area (Illinois River, Illinois River floodplain lakes, upper Mississippi River, middle Mississippi River, and Missouri River) and among years (2006-2011) within sites. Least-squares linear regression was used to characterize the relationship between mean otolith edge $\mathrm{Sr}$ :Ca (last $50 \mu \mathrm{m}$ of laser ablation transect) for bigheaded carps of known recent environmental history and corresponding water Sr:Ca from fish collection locations. A least-squares linear regression was also applied to assess the relationship between water and otolith $\delta^{18} \mathrm{O}$ for bigheaded carps for which recent environmental history was known.

Identification of natal environment for adult Bighead Carp and Silver Carp collected from the Illinois River (fish of unknown origin) using otolith $\mathrm{Sr}: \mathrm{Ca}$ and $\delta^{18} \mathrm{O}$ required characterization of the ranges of otolith $\mathrm{Sr}: \mathrm{Ca}$ and $\delta^{18} \mathrm{O}$ "signatures" representative of each potential natal environment. Otolith core Sr:Ca was used to identify natal river for individual fish and otolith $\delta^{18} \mathrm{O}$ was used as a secondary marker to identify use of floodplain lake or river channel habitat 
during early life. PROC UNIVARIATE in SAS (SAS Institute 2011) was used to determine fifth and ninety-fifth percentiles of water Sr:Ca values for each river during 2006-2011. PROC GLIMMIX (identity link normal distribution) was then used to calculate $95 \%$ confidence limits around predicted otolith $\mathrm{Sr}: \mathrm{Ca}$ values that corresponded with these $5^{\text {th }}$ and $95^{\text {th }}$ percentiles of water Sr:Ca for each river using the regression we developed relating water and otolith $\mathrm{Sr}$ :Ca for bigheaded carps. The 95\% confidence limits around predicted otolith Sr:Ca values were used as thresholds that defined the upper and lower limits of expected otolith $\mathrm{Sr}$ :Ca signatures for each river. These ranges of expected otolith Sr:Ca signatures for each river were used to identify natal river for adult Bighead and Silver carps of unknown origin that were collected from the Illinois River. Natal river was assigned to individual, unknown-origin fish by comparing otolith core Sr:Ca with otolith Sr:Ca signature limits defined for each river. PROC GLIMMIX (identity link normal distribution) was also used to calculate expected upper and lower limits of otolith $\delta^{18} \mathrm{O}$ for fish that used floodplain lake and river channel habitats during early life using $5^{\text {th }}$ and $95^{\text {th }}$ percentiles of water $\delta^{18} \mathrm{O}$ data for these two habitats and the regression relating water and bigheaded carp otolith $\delta^{18} \mathrm{O}$. Individual, unknown-origin fish from the Illinois River were classified as having otolith core $\delta^{18} \mathrm{O}$ values indicative of floodplain lake or river channel residency during early life using the limits of expected otolith $\delta^{18} \mathrm{O}$ signatures defined for each of these two habitats.

Chi square tests were used to assess differences in relative frequencies of adult Bighead Carp and Silver Carp collected in the Illinois River that originated in the Illinois, Mississippi, and Missouri rivers based on otolith core Sr:Ca and differences in relative frequencies of individuals with floodplain lake and river channel otolith core $\delta^{18} \mathrm{O}$ signatures for all individuals combined and by species, river reach (Alton, Peoria-LaGrange, and upper river) and collection 
year (2010 and 2011). Changes in the distributions of otolith core Sr:Ca and $\delta^{18} \mathrm{O}$ values of adult bigheaded carps collected from the Illinois River with fish size (expressed as total length in $\mathrm{mm}$ ) for each species were evaluated using two-dimensional Kolmogorov-Smirnov (2DKS) tests (Garvey et al. 1998). A $P$-value of $\leq 0.05$ was considered significant for all statistical tests, and all statistical analyses other than 2DKS tests were performed using SAS 9.2 (SAS Institute, Inc. 2011).

\section{Results}

Water $\mathrm{Sr}: \mathrm{Ca}$ and $\delta^{18} \mathrm{O}$

Water Sr:Ca differed among the environments that represent potential natal and larval nursery habitats for Bighead and Silver carps present in the Illinois River $(\mathrm{F}=87.50, \mathrm{P}<0.0001$, $\mathrm{df}=4$, 55) (Fig. 2a). Mean water Sr:Ca for the lower Missouri River was $3.25 \mathrm{mmol} / \mathrm{mol}$ and was significantly higher than all other sites. The middle Mississippi River had the second highest mean water $\mathrm{Sr}: \mathrm{Ca}$ at $2.15 \mathrm{mmol} / \mathrm{mol}$; ranges of water $\mathrm{Sr}: \mathrm{Ca}$ for the middle Mississippi and Missouri rivers exhibited some overlap when data across all years (2006-2011) were combined (Fig. 2a). Mean water Sr:Ca values for the upper Mississippi River, Illinois River, and Illinois River floodplain lakes were not significantly different from one another, but were all significantly lower than mean Sr:Ca for the Missouri and middle Mississippi rivers. While the ranges of water Sr:Ca for the Illinois and middle Mississippi rivers overlapped slightly, ranges of water Sr:Ca for the upper Mississippi River and Illinois River floodplain lakes did not overlap with that of the middle Mississippi River (Fig. 2a). No significant differences in water Sr:Ca among years (2006-2011) were present within the Illinois, upper Mississippi, middle Mississippi, or Missouri rivers $(\mathrm{F}=1.66, \mathrm{P}=0.12, \mathrm{df}=14,31)$. 
Analysis of water $\delta^{18} \mathrm{O}$ from all river sites and connected floodplain lakes along the Illinois River revealed a significant difference among sites $(\mathrm{F}=28.06, \mathrm{P}<0.001, \mathrm{df}=1,66)$, with Tukey's HSD test indicating that floodplain lakes differed from each of the river sites ( $\mathrm{P}<$ 0.05; Fig. 2b). This analysis also indicated significant temporal variation in water $\delta^{18} \mathrm{O}$ within sites $(\mathrm{F}=2.60, \mathrm{P}=0.01, \mathrm{df}=9,66)$. Temporal variation was then further analyzed by habitat (river and floodplain lake), which revealed significant temporal variation in water $\delta^{18} \mathrm{O}$ within floodplain lakes but not river sites (lake: $\mathrm{F}=5.60, \mathrm{P}=0.01$, $\mathrm{df}=4,24$; river: $\mathrm{F}=0.87, \mathrm{P}=0.50$, $\mathrm{df}=4,42)$. Substantial overlap in ranges of water $\delta^{18} \mathrm{O}$ was present among the Illinois, upper and middle Mississippi, and Missouri rivers when data from across all sampling years were combined (Fig. 2b).

Relationships between water and otolith chemistry and classification models for determining natal environment of Asian carp

Bigheaded carp otolith Sr:Ca was very strongly correlated with water Sr:Ca for fish of known recent environmental history $\left(\mathrm{r}^{2}=0.96, \mathrm{P}<0.001\right)$ (Fig. 3a). Bigheaded carp otolith $\delta^{18} \mathrm{O}$ was also highly correlated with water $\delta^{18} \mathrm{O}$ for fish of known recent environmental history $\left(\mathrm{r}^{2}=\right.$ 0.94, $\mathrm{P}=0.0013)$ (Fig. 3b).

Differences in water Sr:Ca among the Illinois, middle Mississippi, and Missouri rivers and the highly significant linear relationship between water and otolith $\mathrm{Sr}: \mathrm{Ca}$ for bigheaded carps enabled prediction of upper and lower 95\% confidence limits for otolith $\mathrm{Sr}: \mathrm{Ca}$ "signatures" characteristic of individuals that originated in each of these rivers that could potentially supply recruits to bigheaded carp stocks in the Illinois River. Fifth and ninety-fifth percentiles of water Sr:Ca during 2006-2011 for these rivers were as follows: (Illinois River: 1.11 and 2.10 
mmol/mol; middle Mississippi River: 1.66 and 2.98 mmol/mol; Missouri River: 2.62 and 3.99 mmol/mol). Predicted otolith Sr:Ca values used as thresholds (calculated using PROC GLIMMIX) in the classification model for determining origin of adult bigheaded carps captured from the Illinois River were: Illinois River highest value $=1180 \mathrm{mmol} / \mathrm{mol}$; middle Mississippi River lowest value $=760 \mathrm{mmol} / \mathrm{mol}$; middle Mississippi River highest value $=2796 \mathrm{mmol} / \mathrm{mol}$; Missouri River lowest value $=1954 \mathrm{mmol} / \mathrm{mol}$. Thus, adult bigheaded carps collected from the Illinois River that had otolith core Sr:Ca values $<760 \mathrm{mmol} / \mathrm{mol}$ were designated as having originated from the Illinois River, fish with otolith core $\mathrm{Sr}$ Ca values between $760 \mathrm{mmol} / \mathrm{mol}$ and $1180 \mathrm{mmol} / \mathrm{mol}$ were classified as having originated in either the Illinois River or the middle Mississippi River, fish with otolith core Sr:Ca values between $1180 \mathrm{mmol} / \mathrm{mol}$ and 1954 $\mathrm{mmol} / \mathrm{mol}$ were determined to have originated in the middle Mississippi River, fish with otolith core Sr:Ca values between $1954 \mathrm{mmol} / \mathrm{mol}$ and $2796 \mathrm{mmol} / \mathrm{mol}$ were designated as having originated in either the middle Mississippi River or the Missouri River, and bigheaded carps with otolith core Sr:Ca values > $2796 \mathrm{mmol} / \mathrm{mol}$ were classified as having originated in the Missouri River. Substantial overlap in water $\mathrm{Sr}: \mathrm{Ca}$ and $\delta^{18} \mathrm{O}$ between the Illinois and upper Mississippi rivers prohibited distinction of fish from these two rivers using these markers. Thus, the 'Illinois River' category in our classification model of natal environment included individuals that may have originated in the Illinois River or in the lowermost section of the upper Mississippi River; the Illinois River flows into pool 26 of the upper Mississippi River.

Threshold otolith $\delta^{18} \mathrm{O}$ values (calculated using PROC GLIMMIX) that distinguished residency in floodplain lake and river channel habitats were: floodplain lake lightest otolith $\delta^{18} \mathrm{O}$ value $=-6.94 \%$; river heaviest otolith $\delta^{18} \mathrm{O}$ value $=-6.00 \%$. Thus, early life habitat of individual adult bigheaded carps collected from the Illinois River (fish of unknown origin) was 
determined from otolith core $\delta^{18} \mathrm{O}$ as follows: fish with otolith core $\delta^{18} \mathrm{O}>-6.00 \%$ represented individuals that used floodplain lake habitat during early life, otolith core $\delta^{18} \mathrm{O}$ values $<-6.00 \%$ and $>-6.94 \%$ were inconclusive with respect to whether fish used river or floodplain lake habitat during early life, and otolith core $\delta^{18} \mathrm{O}$ values $<-6.94 \%$ were indicative of individuals that used river channel habitat during early life.

Natal environments of Illinois River Bighead and Silver carp

The majority of adult bigheaded carps collected from the Illinois River originated in the Illinois River or the lowermost section of the upper Mississippi River and an estimated six to 24 percent of fish sampled originated in the middle Mississippi or Missouri rivers. The proportions of fish determined to have originated in each river (Illinois River, middle Mississippi River, or Missouri River $)$ were unequal $\left(\chi^{2}=948.31, \mathrm{P}<0.001\right)$. Further analysis revealed a significant difference in the relative frequency of individuals from the different potential natal rivers between Silver and Bighead carps $\left(\chi^{2}=83.65, \mathrm{P}<0.001\right)$ (Fig. 4). Of the 195 Bighead Carp sampled, 190 possessed an Illinois River otolith core Sr:Ca signature, with the other five fish displaying an otolith core $\mathrm{Sr}: \mathrm{Ca}$ signature that represented either an Illinois River or middle Mississippi River origin. In contrast, $11 \%$ of Silver Carp collected were immigrants to the Illinois River (primarily from the middle Mississippi River) and an additional 28\% of adult Silver Carp exhibited an otolith core Sr:Ca signature that represented either an Illinois River or middle Mississippi River origin. Frequency distribution of natal environments for both Silver Carp and Bighead Carp did not differ among the three reaches of the Illinois River (Silver Carp $\chi^{2}=7.52, \mathrm{P}=0.48$; Bighead Carp $\chi^{2}=3.82, \mathrm{P}=0.15$ ) or between sampling years (Silver Carp $\chi^{2}$ 
$=1.86, \mathrm{P}=0.76$; Bighead Carp $\left.\chi^{2}=.02, \mathrm{P}=0.89\right)$. The distribution of otolith core $\mathrm{Sr}$ :Ca values did not change significantly with fish total length $(\mathrm{D}=0.016, \mathrm{P}=0.80)$.

Analysis of otolith core $\delta^{18} \mathrm{O}$ for adult Bighead and Silver carps collected from the Illinois River revealed that the majority of fish primarily used river channel habitats rather than floodplain lakes during their first year of life. Thirty-two fish (8.5\%) used floodplain lake habitats during early life, 233 (62.1\%) used river channel habitat and 110 (29.3\%) fell into the uncertain category of early life habitat use due to overlapping otolith $\delta^{18} \mathrm{O}$ values predicted for river- and floodplain lake-resident fish $\left(\chi^{2}=164.30, \mathrm{P}<0.001\right)$. The frequency distribution of individuals that used river channel and floodplain lake habitats during early life differed between Silver and Bighead carps $\left(\chi^{2}=50.56, \mathrm{P}<0.001\right)$ (Fig. 5). The frequency distribution of individuals that used river channel and floodplain lake habitats during early life also differed among the three reaches of the Illinois River for both species (Bighead Carp: $\chi^{2}=16.83, \mathrm{P}<$ 0.01; Silver Carp: $\left.\chi^{2}=37.43, \mathrm{P}<0.001\right) ; 17$ of 32 fish with floodplain lake otolith core $\delta^{18} \mathrm{O}$ signatures were collected in the upper river and 10 individuals with floodplain lake otolith core $\delta^{18} \mathrm{O}$ signatures were collected from the Peoria-LaGrange reach. Two-dimensional KolmogorovSmirnov analysis revealed Silver Carp > $501 \mathrm{~mm}$ total length displayed much greater variation (higher frequency of less negative values) in otolith core $\delta^{18} \mathrm{O}$ compared to individuals less than this length $(\mathrm{D}=0.1003, \mathrm{P}=0.002)$ (Fig. 6). In contrast, the distribution of Bighead Carp otolith core $\delta^{18} \mathrm{O}$ values did not change with fish size $(\mathrm{D}=0.04, \mathrm{P}=0.31)$.

\section{Discussion}

Significant linear relationships between water and otolith $\mathrm{Sr}: \mathrm{Ca}$ and between water and otolith $\delta^{18} \mathrm{O}$ for bigheaded carps indicate that these intrinsic chemical markers can be used to 
reconstruct environmental history of Bighead Carp and Silver Carp in areas where persistent geographic differences in water $\mathrm{Sr}: \mathrm{Ca}$ and $\delta^{18} \mathrm{O}$ signatures are present and of sufficient magnitude to yield corresponding spatial differences in otolith $\mathrm{Sr}: \mathrm{Ca}$ and $\delta^{18} \mathrm{O}$. Previous studies have reported linear relationships between water and otolith $\mathrm{Sr}: \mathrm{Ca}$ and water and otolith $\delta^{18} \mathrm{O}$ for other fish species in fresh water (Wells et al. 2003; Walther and Thorrold 2008; Zeigler and Whitledge 2010; Smith and Whitledge 2011). Similarity of slopes and intercepts among fish species for relationships between water and otolith $\delta^{18} \mathrm{O}$ have been observed in prior studies (Patterson et al. 1993; Zeigler and Whitledge 2010). In contrast, otolith Sr:Ca was consistently 2-4 times higher for Bighead and Silver carps compared to fishes native to the Mississippi River basin over the range of water Sr:Ca present in the Illinois, Mississippi, and lower Missouri rivers (Zeigler and Whitledge 2010; Smith and Whitledge 2011). Similarly high otolith Sr:Ca in relation to water Sr:Ca has been observed in lapilli otoliths from Grass Carp (Chapman et al. 2013), and additional study is needed to elucidate causes of elevated Sr:Ca in lapilli otoliths of Asian carps. Collectively, results of our study and Chapman et al. (2013) indicate that interpretation of otolith Sr:Ca data from Asian carps of unknown environmental history will require use of relationships between water and otolith Sr:Ca developed specifically for these species.

The applicability of otolith microchemistry and stable isotopic compositions as natural indicators of fish environmental history depends on the persistence of geographically based differences in water chemistry over time. Our results indicated that previously reported differences in water $\mathrm{Sr}: \mathrm{Ca}$ among the Illinois, Missouri, and Mississippi rivers driven by differences in bedrock geology of their watersheds (Whitledge 2009; Zeigler and Whitledge 2011; Smith and Whitledge 2011; Phelps et al. 2012) persisted over the 6-year time period from 
2006-2011. Median water Sr:Ca for the upper Mississippi River $(1.13 \mathrm{mmol} / \mathrm{mol})$, the middle Mississippi River (2.02 mmol/mol), and the lower Missouri River (3.25 mmol/mol) during 19962000 reported by Kelly et al. (2001) were within the ranges of Sr:Ca values measured in each of these respective river segments during our study, further indicating persistence of differences in water Sr:Ca signatures among these rivers across years. Although some overlap in ranges of water Sr:Ca between the Illinois and middle Mississippi rivers and between the middle Mississippi and Missouri rivers occurred when data from 2006-2011 were combined, the distributions of water $\mathrm{Sr}: \mathrm{Ca}$ for each of these rivers were sufficiently different to yield broad ranges of water Sr:Ca values that were characteristic of a particular river or a subset of these river segments (e.g., water $\mathrm{Sr}$ :Ca values $>2.1 \mathrm{mmol} / \mathrm{mol}$ were observed only in the middle Mississippi and Missouri rivers and only the Missouri River had water Sr:Ca values > 3 $\mathrm{mmol} / \mathrm{mol})$. Differences in water Sr:Ca among rivers that represented potential natal environments for Bighead Carp and Silver Carp collected from the Illinois River enabled development and application of a single classification model to identify natal river for individual fish from otolith core Sr:Ca regardless of fish size or year class. While we did not age Bighead Carp or Silver Carp collected for this study, most of the fish were likely between age-3 and age- 6 based on total lengths of collected individuals (mean $653 \mathrm{~mm} \pm 171.5 \mathrm{~mm} \mathrm{SE}$ ) and studies of growth rates and age structure for Bighead Carp and Silver Carp in the middle Mississippi and Illinois rivers (Williamson and Garvey 2005; Garvey et al. 2012).

Differences in water $\delta^{18} \mathrm{O}$ values between river and floodplain lake habitats were useful as a secondary marker for determining early life habitat use by Bighead and Silver carps, although flooding along the Illinois River may have limited the ability to detect fish use of floodplain lake habitats during some years. Mean water $\delta^{18} \mathrm{O}$ in floodplain lakes was 
significantly less negative (enriched in ${ }^{18} \mathrm{O}$ ) compared to river channel habitats due to longer water residence times and greater evaporative fractionation in floodplain lakes, particularly during periods of normal to low discharge during summer and fall in the Illinois River (Zeigler and Whitledge 2010). Water $\delta^{18} \mathrm{O}$ values for the Illinois, upper and middle Mississippi, and lower Missouri rivers measured during this study fell within the ranges of $\delta^{18} \mathrm{O}$ values previously reported for these rivers (Coplen and Kendall 2000; Winston and Criss 2003; Whitledge 2009; Zeigler and Whitledge 2010, 2011; Myers et al. 2012). Floodplain lakes exhibited more temporal variability in water $\delta^{18} \mathrm{O}$ than river channel habitats due to fluctuations in connectivity and hydrologic exchange with the river. Flood pulses occurred in the Illinois River during all or part of the summer and fall (June through October) each year from 2007-2010 that temporarily reduced or eliminated differences in water $\delta^{18} \mathrm{O}$ between the river and its connected floodplain lakes. In contrast, flooding did not occur during summer or fall 2005-2006; discharge for the Illinois River at Valley City, IL (39 $\left.42^{\prime} 12^{\prime \prime} \mathrm{N}, 90^{\circ} 38^{\prime} 43^{\prime \prime} \mathrm{W}\right)$ did not exceed $566 \mathrm{~m}^{3} / \mathrm{s}$ during June-November in either 2005 or 2006 (USGS 2014). The absence of flooding in the Illinois River during summer and fall 2005 and 2006 and frequent flooding during summer and fall 2007-2010 may explain the significantly greater frequency of individuals that exhibited floodplain lake otolith core $\delta^{18} \mathrm{O}$ signatures among Silver Carp > $501 \mathrm{~mm}$ total length compared to smaller (and presumably younger) individuals. Future research applying $\delta^{18} \mathrm{O}$ or $\mathrm{Sr}: \mathrm{Ca}$ as natural tracers of fish environmental history in the Illinois, Mississippi, and Missouri rivers and floodplain lake habitats should monitor water $\delta^{18} \mathrm{O}$ or $\mathrm{Sr}: \mathrm{Ca}$ to verify that differences among environments observed in this study and prior studies are still present.

In addition to the floods during 2007-2010 that periodically reduced or eliminated differences in water $\delta^{18} \mathrm{O}$ between the river and its connected floodplain lakes, several other 
factors may explain the relatively low percentages of Bighead and Silver carps that exhibited definitive otolith core $\delta^{18} \mathrm{O}$ core values reflective of use of floodplain lake habitat rather than river channel habitat during early life. While age-0 Bighead and Silver carps commonly occur in floodplain lakes (Pegg et al. 2002; Wang et al. 2003; DeGrandchamp et al. 2007), use of such habitats as nursery areas may be facultative for these species. Low-velocity nearshore and backwater habitats that do not differ in water $\delta^{18} \mathrm{O}$ from the main river channel may represent the primary habitats used by age-0 Bighead and Silver carps; these habitats are more extensive than connected backwater lakes and are known to support recruitment in the middle Mississippi River, which lacks connected floodplain lakes (Lohmeyer and Garvey 2009). Relatively low abundance of connected floodplain lakes along the Illinois River compared to the number historically present (Koel and Sparks 2002) may also account for the low percentage of individuals with floodplain lake otolith core $\delta^{18} \mathrm{O}$ signatures among adult bigheaded carps collected from the Illinois River. Identifying individuals that used floodplain lake habitats during their first year of life may also have been limited by the resolution of otolith subsamples analyzed for $\delta^{18} \mathrm{O}$, which likely encompassed $\mathrm{CaCO}_{3}$ deposited over several months during age0. Thus, only individuals that used floodplain lakes for the majority of their first year of life would have exhibited floodplain lake otolith core $\delta^{18} \mathrm{O}$ signatures and been classified as having used this type of habitat.

A higher percentage of adult Bighead Carp collected from the Illinois River exhibited floodplain lake $\delta^{18} \mathrm{O}$ signatures in their otolith cores compared to adult Silver Carp. This is consistent with results of otolith $\mathrm{Sr}: \mathrm{Ca}$ analysis, which indicated that a larger proportion of Bighead Carp originated in the Illinois River rather than in the middle Mississippi or lower Missouri rivers compared to Silver Carp, as the Illinois River contains substantially more 
connected floodplain lake habitat than either the middle Mississippi or lower Missouri rivers. Interestingly, the highest frequency of occurrence of individuals with floodplain lake otolith core $\delta^{18} \mathrm{O}$ signatures for both species occurred among adult fish collected from the upper Illinois River, a reach that contains very limited floodplain lake habitat. No evidence of reproduction (including spawning, presence of eggs or collection of age-0 individuals) by Bighead or Silver carps in the upper river was observed prior to 2013 (Baerwaldt et al. 2013). Thus, the higher frequency of individuals with floodplain lake otolith core $\delta^{18} \mathrm{O}$ signatures in the upper river compared to the Peoria-LaGrange and Alton reaches is indicative of these downstream river reaches functioning as recruitment sources for Bighead and Silver carps present in the upper river.

The majority of adult Bighead and Silver carps collected from all reaches of the Illinois River in 2010 and 2011 originated in the Illinois River, reflective of establishment of both species and consistent with documented reproduction in the middle and lower sections of the Illinois River (Pegg et al. 2002; DeGrandchamp et al. 2007; Baerwaldt et al. 2013). It is likely that some of the individuals identified as Silver Carp were Bighead-Silver carp hybrids (Lamer et al. 2010); future applications of otolith chemistry to bigheaded carps should determine whether principle recruitment sources differ among hybrids and parental species. Otolith core Sr:Ca data indicated that $97 \%$ of adult Bighead Carp collected from the Illinois River originated in the Illinois River itself, with only a few fish having potentially originated in the middle Mississippi River. This finding is somewhat surprising considering that Bighead Carp were detected and became established in the Illinois River prior to Silver Carp (Peters et al. 2006; Irons et al. 2007). We cannot rule out the possibility that some individual Bighead and Silver carps that originated in the lowermost section of the upper Mississippi River may have been classified as being of 
Illinois River origin due to substantial overlap in water $\mathrm{Sr}: \mathrm{Ca}$ and $\delta^{18} \mathrm{O}$ signatures between the Illinois and upper Mississippi Rivers. However, it is unlikely that the upper Mississippi River upstream from the Illinois River confluence represented a substantial source for adult bigheaded carps collected from the Illinois River given the much lower densities of larval bigheaded carps in the Mississippi River above Lock and Dam 25 in comparison to the lower Illinois River, pool 26 of the upper Mississippi River (the furthest downstream impoundment in the Mississippi River into which the Illinois River flows), and the middle Mississippi River (DeGrandchamp et al. 2007; Lohmeyer and Garvey 2009). In addition, recent analysis of otolith core Sr:Ca for adult Bighead and Silver carps collected from pools 20-26 of the upper Mississippi River indicated that $84 \%$ of individuals sampled originated in other river reaches with higher $\mathrm{Sr}$ :Ca signatures (primarily the middle Mississippi River; Whitledge, unpublished data), suggesting that the upper Mississippi River is not a substantial recruitment source for Bighead or Silver carps in this portion of the Missisippi River basin. Future applications of otolith microchemistry and stable isotope analyses to infer environmental history of bigheaded carps in the Mississippi or Illinois Rivers should consider inclusion of strontium isotope ratios $\left({ }^{87} \mathrm{Sr} /{ }^{86} \mathrm{Sr}\right)$ as a potential additional marker to distinguish fish from the Illinois and upper Mississippi rivers.

In contrast to Bighead Carp, an estimated 11-38\% of adult Silver Carp were immigrants to the Illinois River that originated in the middle Mississippi River or, for a relatively small percentage of these individuals, the lower Missouri River. The substantial contribution of the middle Mississippi River to Silver Carp recruitment in the Illinois River is likely a consequence of consistently high annual larval production in the middle Mississippi River (Lohmeyer and Garvey 2009) and the capability of adult fish to move several kilometers per day (DeGrandchamp et al. 2008). The propensity for adult Silver Carp to travel considerable 
distances in a short time, particularly during periods of high river discharge (DeGrandchamp et al. 2008) also likely explains the consistent proportion of immigrant Silver Carp (fish that originated in the middle Mississippi or Missouri rivers) observed among fish collected from the Alton, Peoria-LaGrange, and Upper River reaches of the Illinois River. The absence of significant differences in either the frequency distribution of natal environments for bigheaded carps between 2010 and 2011 collections or in the distribution of otolith core Sr:Ca with fish size suggests at least some degree of inter-annual consistency in recruitment sources for stocks of these species in the Illinois River.

Our results indicate that efforts to substantially reduce abundance of bigheaded carps in the Illinois River should continue to focus on the Illinois River and the contiguous pool 26 of the upper Mississippi River, but will likely need to be expanded to include the middle Mississippi River, and potentially the lower Missouri River, for sustainable control of Silver Carp. If enhanced commercial harvest is restricted to the Illinois River, it appears likely that immigrants would replenish Silver Carp stocks in the Illinois River without additional efforts to limit fish movement such as installation of barriers at dams (Conover et al. 2007) given the substantial contribution of recruits from the middle Mississippi River to all three reaches of the Illinois River. Our findings regarding recruitment sources of Bighead and Silver carps in the Illinois River will be important for refining recently developed simulation models for predicting population responses to harvest and development of spatially-explicit strategies to achieve fishery-induced collapse (Tsehaye et al. 2013). We also anticipate that otolith microchemistry and stable isotope analyses may be applicable to other portions of the expanding, non-native ranges of Bighead and Silver carps to identify their principle recruitment sources and inform development of control strategies to limit their range expansion and impacts. 


\section{Acknowledgments}

Funding for this research was provided by the Illinois Department of Natural Resources. We thank David Dettman (Environmental Isotope Laboratory, Department of Geosciences, University of Arizona), Eric Freeburg and Robyn Hannigan (University of MassachusettsBoston), Tim Howe and Norma Haubenstock (Alaska Stable Isotope Facility, University of Alaska-Fairbanks), Alan Shiller (Center for Trace Analysis, University of Southern Mississippi) and Mihai Lefticariu (Southern Illinois University Mass Spectrometry Facility), for stable isotope and trace element analyses of otoliths and water samples. Dave Glover, Wes Bouska, and Neil Rude assisted with fish collections. We also thank Jon Amberg and Duane Chapman (USGS), Greg Conover (US Fish \& Wildlife Service) and Quinton Phelps (Missouri Department of Conservation) for providing fish used in this study. 


\section{References}

Baerwaldt K, Benson A, Irons K (2013) Asian carp distribution in North America. Report to the Asian Carp Regional Coordinating Committee, April 2013, 8 pp.

Campana SE, Thorrold SR (2001) Otoliths, increments, and elements: keys to a comprehensive understanding of fish populations? Can J Fish Aquat Sci 58:30-38.

Chapman DC, Davis JJ, Jenkins JA, Kocovsky PA, Miner JG, Farver J, Jackson PR (2013) First evidence of grass carp recruitment in the Great Lakes Basin. J Great Lakes Res 39:547554.

Chick JH, Pegg MA (2001) Invasive carp in the Mississippi River Basin. Science 292(5525):2250-2251.

Conover G, Simmonds R, Whalen M (eds) (2007) Management and control plan for bighead, black, grass, and silver carps in the United States. Asian Carp Working Group. Aquatic Nuisance Species Task Force, Washington, DC, 223 pp.

Coplen T, Kendall C (2000) Stable hydrogen and oxygen isotope ratios for selected sites of the U. S. Geological Survey's NASQAN and BENCHMARK surface water networks. U.S. Geological Survey Open-file Report 00-160, Reston, VA, 409 pp.

Crook DA, Gillanders BM (2006) Use of otolith chemical signatures to estimate carp recruitment sources in the Mid-Murray River, Australia. River Res Appl 22:871-879.

Crook DA, Macdonald JI, McNeil DG, Gilligan DM, Asmus M, Maas R, Woodhead J (2013) Recruitment sources and dispersal of an invasive fish in a large river system as revealed by otolith chemistry analysis. Can J Fish Aquat Sci 70:953-963.

Cudmore B, Mandrak NE (2011) Assessing the biological risk of Asian Carps to Canada. In Chapman DC, Hoff MH (eds) Invasive Asian Carps in North America. American Fisheries Society, Bethesda, pp. 15-30.

DeGrandchamp KL, Garvey JE, Csoboth LA (2007) Linking adult reproduction and larval density of invasive carp in a large river. Trans Am Fish Soc 136:1327-1334.

DeGrandchamp KL, Garvey JE, Colombo RE (2008) Movement and habitat selection by invasive Asian carps in a large river. Trans Am Fish Soc 137:45-56.

Deters JE, Chapman DC, McElroy B (2013) Location and timing of Asian carp spawning in the Lower Missouri River. Environ Biol Fish 96:617-629.

Dufour E, Patterson W, Hook T, Rutherford E (2005) Early life history of Lake Michigan alewives (Alosa pseudoharengus) inferred from intra-otolith stable isotope ratios. Can J Fish Aquat Sci 62:2362-2370. 
Garvey JE, Marschall EA, Wright RA (1998) From star charts to stoneflies: detecting relationships in continuous bivariate data. Ecology 79:442-447.

Garvey JE, Sass GG, Trushenski J, Glover D, Charlebois PM, Levengood J, Roth B, Whitledge G, Small BC, Tripp SJ, Secchi S (2012) Fishing down the Bighead and Silver carps: reducing the risk of invasion to the Great Lakes. Project completion report. U.S. Fish and Wildlife Service and Illinois Department of Natural Resources.

Irons K, Sass G, McClelland M, Stafford J (2007) Reduced condition factor of two native fish species coincident with invasion of non-native Asian carps in the Illinois River, U.S.A. Is this evidence for competition and reduced fitness? J Fish Biol 71:258-273.

Irons KS, Sass GG, McClelland MA, O’Hara TM (2011) Bighead Carp invasion of the La Grange Reach of the Illinois River: insight from the Long Term Resource Monitoring Program. In Chapman DC, Hoff MH (eds) Invasive Asian Carps in North America. American Fisheries Society, Bethesda, pp. 31-50.

Jelks HL, Walsh SJ, Burkhead NM, Contreras-Balderas S, Diaz-Pardo E, Hendrickson DA, Lyons J, Mandrak NE, McCormick F, Nelson JS, Platania SP, Porter BA, Renaud CB, Schmitter-Soto JJ, Taylor EB, Warren ML (2008) Conservation status of imperiled North American freshwater and diadromous fishes. Fisheries 33:372-407.

Jerde CL, Mahon AR, Chadderton WL, Lodge DM (2011) "Sight-unseen" detection of rare aquatic species using environmental DNA. Conserv Lett 4:150-157.

Kelly AM, Engle CR, Armstrong ML, Freeze M, Mitchell AJ (2011) History of introductions and governmental involvement in promoting the use of Grass, Silver, and Bighead carps. In Chapman DC, Hoff MH (eds) Invasive Asian Carps in North America. American Fisheries Society, Bethesda, pp. 163-174.

Kelly VJ, Hooper RP, Aulenbach BT, Janet M (2001) Concentrations and annual fluxes for selected water-quality constituents from the USGS National Stream Quality Accounting Network (NASQAN), 1996-2000. Retrieved from http://pubs.usgs.gov/wri/wri014255/results.htm on 1 May 2014.

Kendall C, Caldwell E (1998) Fundamentals of isotope geochemistry. In Kendall C, McDonnell JJ (eds) Isotope Tracers in Catchment Hydrology, Elsevier, Amsterdam pp. 51-86.

Kennedy BP, Klaue A, Blum JD, Folt CL, Nislow KH (2002) Reconstructing the lives of fish using $\mathrm{Sr}$ isotopes in otoliths. Can J Fish Aquat Sci 59:925-929.

Koel T, Sparks R (2002) Historical patterns of river stage and fish communities as criteria for operations of dams on the Illinois River. River Res Appl 18:3-19.

Kolar CS, Lodge DM (2002) Ecological predictions and risk assessment for alien fishes in North America. Science 298:1233-1236. 
Lamer JT, Dolan CR, Petersen JL, Chick JH, Epifanio JM (2010) Introgressive hybridization between bighead carp and silver carp in the Mississippi and Illinois rivers. N Am J Fish Manage 30:1452-1461.

Lodge DM, Williams S, MacIsaac HJ, Hayes KR, Leung B, Reichard S, Mack RN, Moyle PB, Smith M, Andow DA, Carlton JT, McMichael A (2006) Biological invasions: recommendations for U.S. policy and management. Ecol Appl 16:2035-2054.

Lohmeyer A, Garvey J (2009) Placing the North American invasion of Asian carp in a spatially explicit context. Biol Invasions 11:905-916.

Ludsin SA, Fryer BJ, Gagnon JE (2006) Comparison of solution-based versus laser ablation inductively coupled plasma mass spectrometry for analysis of larval fish microelemental composition. Trans Am Fish Soc 135:218-231.

Mahon AR, Jerde CL, Chadderton WL, Lodge DM (2011) Using environmental DNA to elucidate the Asian Carp (genus Hypophthalmichthys) invasion front in the Chicago Area Waterway System. Integr Comp Biol 51:e1-e157.

Melancon S, Fryer BJ, Ludsin SA, Gagnon JA, Yang Z (2005) Effects of crystal structure on the uptake of metals by lake trout (Salvelinus namaycush) otoliths. Can J Fish Aquat Sci 62:2609-2619.

Moy PB, Polls I, Dettmers JM (2011) The Chicago Sanitary and Ship Canal aquatic nuisance species dispersal barrier. In Chapman DC, Hoff MH (eds) Invasive Asian Carps in North America. American Fisheries Society, Bethesda, pp. 127-137.

Munro AR, McMahon TE, Ruzycki JR (2005) Natural chemical markers identify source and date of introduction of an exotic species: lake trout (Salvelinus namaycush) in Yellowstone Lake. Can J Fish Aquat Sci 62:79-87.

Myers DJ, Whitledge GW, Whiles MR (2012) Evaluation of $\delta \mathrm{D}$ and $\delta^{18} \mathrm{O}$ as natural markers of invertebrate source environment and dispersal in the middle Mississippi River-floodplain ecosystem. River Res Appl 28:135-142.

Patterson W, Smith G, Lohmann K (1993) Continental paleothermometry and seasonality using the isotopic composition of aragonitic otoliths of freshwater fishes. Geophys Monogr 78:191-202.

Pegg M, Lemke AM, Stoeckel JA (2002) Establishment of bighead carp in an Illinois River floodplain lake: A potential source population for the Illinois River. J Freshwater Ecol 17:161-163.

Peters L, Pegg M, Reinhardt U (2006) Movements of adult radio-tagged bighead carp in the Illinois River. Trans Am Fish Soc 135:1205-1212. 
Phelps QE, Whitledge GW, Tripp SJ, Smith KT, Garvey JE, Herzog DP, Ostendorf DE, Ridings JW, Crites JW, Hrabik RA, Doyle WJ, Hill TD (2012) Identifying river of origin for age0 Scaphirhynchus sturgeons in the Missouri and Mississippi rivers using fin ray microchemstry. Can J Fish Aquat Sci 69:930-941.

Sala OE, Chapin FS, Armesto JJ, Berlow E, Bloomfield J, Dirzo R, Huber-Sanwald E, Huenneke LF, Jackson RB, Kinzig A, Leemans R, Lodge DM, Mooney HA, Oesterheld M, Poff NL, Sykes MT, Walker BH, Walker M, Wall DH (2000) Global biodiversity scenarios for the year 2100. Science 287:1770-1774.

Sampson S, Chick J, Pegg M (2009) Diet overlap among two Asian carp and three native fishes in backwater lakes on the Illinois and Mississippi rivers. Biol Invasions 11:483-496.

SAS Institute, Inc. (2011) SAS/STAT User's Guide, Version 9.2. SAS Institute, Inc., Cary, NC.

Sass G, Cook T, Irons K, McClelland M, Michaels N, O'Hara TM, Stroub M (2010) A markrecapture population estimate for invasive Silver Carp (Hypophthalmichthys molitrix) in the La Grange Reach, Illinois River. Biol Invasions 12:433-436.

Schrank SJ, Braaten PJ, Guy CS (2001) Spatiotemporal variation in density of larval bighead carp in the Lower Missouri River. Trans Am Fish Soc 130:809-814.

Schrank SJ, Guy CS, Fairchild JF (2003) Competitive interactions between age-0 Bighead Carp and Paddlefish. Trans Am Fish Soc 132:1222-1228.

Shen J, Gao Y (2012) Stable isotope analyses in otoliths of silver carp: a pilot study in identification of natal sources and stock differences. Environ Biol Fish 95:445-453.

Shiller, AM (2003) Syringe filtration methods for examining dissolved and colloidal trace element distributions in remote field locations. Environ Sci Technol 37:3953-3957.

Smith KT, Whitledge GW (2011) Trace element and stable isotopic signatures in otoliths and pectoral spines as potential indicators of catfish environmental history. Catfish 2010: Proceedings of the $2^{\text {nd }}$ International Catfish Symposium. American Fisheries Society Symposium 77:645-660.

Tsehaye I, Catalano M, Sass G, Glover D, Roth B (2013) Prospects for fishery-induced collapse of invasive Asian carp in the Illinois River. Fisheries 38:445-454.

United States Geological Survey (USGS) (2014) National Water Information System: Web Interface. Retrieved from http://waterdata.usgs.gov/il/nwis/uv?05586100 on 2 May 2014.

Wang Z, Wu Q, Ye Y, Tong J (2003) Silver carp Hypophthalmichthys molitrix in the Poyang Lake belong to the Gangjiang River population rather than to the Changjiang River population. Environ Biol Fish 68:261-267. 
Walther BD, Thorrold SR (2008) Continental-scale variation in otolith geochemistry of juvenile American shad (Alosa sapidissima). Can J Fish Aquat Sci 65:2623-2635.

Wells B, Rieman B, Clayton J, Horan D, Jones C (2003) Relationships between water, otolith, and scale chemistries of westslope cutthroat trout from the Coeur d'Alene River, Idaho: the potential application of hard-part chemistry to describe movements in freshwater. Trans Am Fish Soc 132:409-424.

Whitledge GW, Johnson BM, Martinez PJ, Martinez AM (2007) Sources of nonnative centrarchids in the upper Colorado river revealed by stable isotope and microchemical analysis of otoliths. Trans Am Fish Soc 136:1263-1275.

Whitledge GW (2009) Otolith microchemistry and isotopic composition as potential indicators of fish movement between the Illinois River drainage and Lake Michigan. J Great Lakes Res 35:101-106.

Williamson CJ, Garvey JE (2005) Growth, fecundity and diets of newly established silver carp in the middle Mississippi river. Trans Am Fish Soc 134:1423-1430.

Winston WE, Criss RE (2003) Oxygen isotope and geochemical variations in the Missouri River. Environ Geol 43:546-556.

Zeigler JM, Whitledge GW (2010) Assessment of otolith chemistry for identifying source environment of fishes in the lower Illinois River, Illinois. Hydrobiologia 638:109-119.

Zeigler JM, Whitledge GW (2011) Otolith trace element and stable isotopic compositions differentiate fishes from the Middle Mississippi River, its tributaries, and floodplain lakes. Hydrobiologia 66:289-302. 


\section{Figure Captions}

Fig. 1. Locations of the three reaches of the Illinois River (Alton, Peoria-LaGrange, and upper river) where adult Bighead Carp and Silver Carp were collected during 2010-2011. Other rivers that represent potential natal environments for bigheaded carps in the Illinois River (upper and middle Mississippi Rivers and Missouri River) and principle tributaries of the upper Illinois River are also shown. Solid lines across the Illinois River indicate locations of locks and dams.

Fig. 2. Boxplots displaying the ranges, medians, and inter-quartile ranges for (a) water Sr:Ca and (b) water $\delta^{18} \mathrm{O}$ from potential natal environments for Bighead Carp and Silver Carp in the Illinois River. Lakes $=$ Floodplain lakes $\left(\mathrm{Sr}: \mathrm{Ca} \mathrm{n}=35 ; \delta^{18} \mathrm{O} \mathrm{n}=29\right), \mathrm{ILR}=$ Illinois River $(\mathrm{Sr}: \mathrm{Ca} \mathrm{n}=24$; $\left.\delta^{18} \mathrm{O} n=22\right)$, UMS = Upper Mississippi River $(\mathrm{n}=11), \mathrm{MMS}=$ Middle Mississippi River $(\mathrm{n}=$ 11), MOR = Missouri River $(\mathrm{n}=12)$, sampled during June, August, and October 2006-2011.

Fig. 3. Relationships between (a) otolith Sr:Ca water Sr:Ca $\left(y=1199.34 x-1084.3 ; r^{2}=0.96\right.$, $\mathrm{p}<0.001)$ and (b) otolith $\delta^{18} \mathrm{O}$ and water $\delta^{18} \mathrm{O}\left(\mathrm{y}=0.61 \mathrm{x}-3.10 ; \mathrm{r}^{2}=0.94, \mathrm{p}=0.0013\right)$ for bigheaded carps of known origin. Symbols represent means from collection locations \pm SE.

Fig. 4. Natal river for (a) adult Bighead Carp $(n=195)$ and (b) adult Silver Carp $(n=260)$ collected from the Illinois River during 2010-2011 determined from otolith core Sr:Ca for individual fish. Values represent percentages of individuals collected that originated from each river $($ ILR = Illinois River; ILMS = Illinois River or middle Mississippi River origin; MOR = Missouri River; MMSR = middle Mississippi River; MSMO = middle Mississippi River or Missouri River origin). 
Fig. 5. Comparison of early life habitat use between (a) Bighead Carp ( $n=137)$ and (b) Silver Carp $(n=238)$ collected from the Illinois River during 2010-2011. Early life habitat use (river, floodplain lake, or uncertain) for individual fish was determined using otolith core $\delta^{18} \mathrm{O}$.

Fig. 6. Adult Silver Carp $(\mathrm{n}=238)$ otolith $\operatorname{core} \delta^{18} \mathrm{O}$ signatures plotted against total length for individual fish collected from the Illinois River during 2010-2011. Vertical dotted line represents total length $(501 \mathrm{~mm})$ at which a significant shift in the distribution of otolith core $\delta^{18} \mathrm{O}$ values was detected using a two-dimensional Kolmogorov-Smirnov test. 


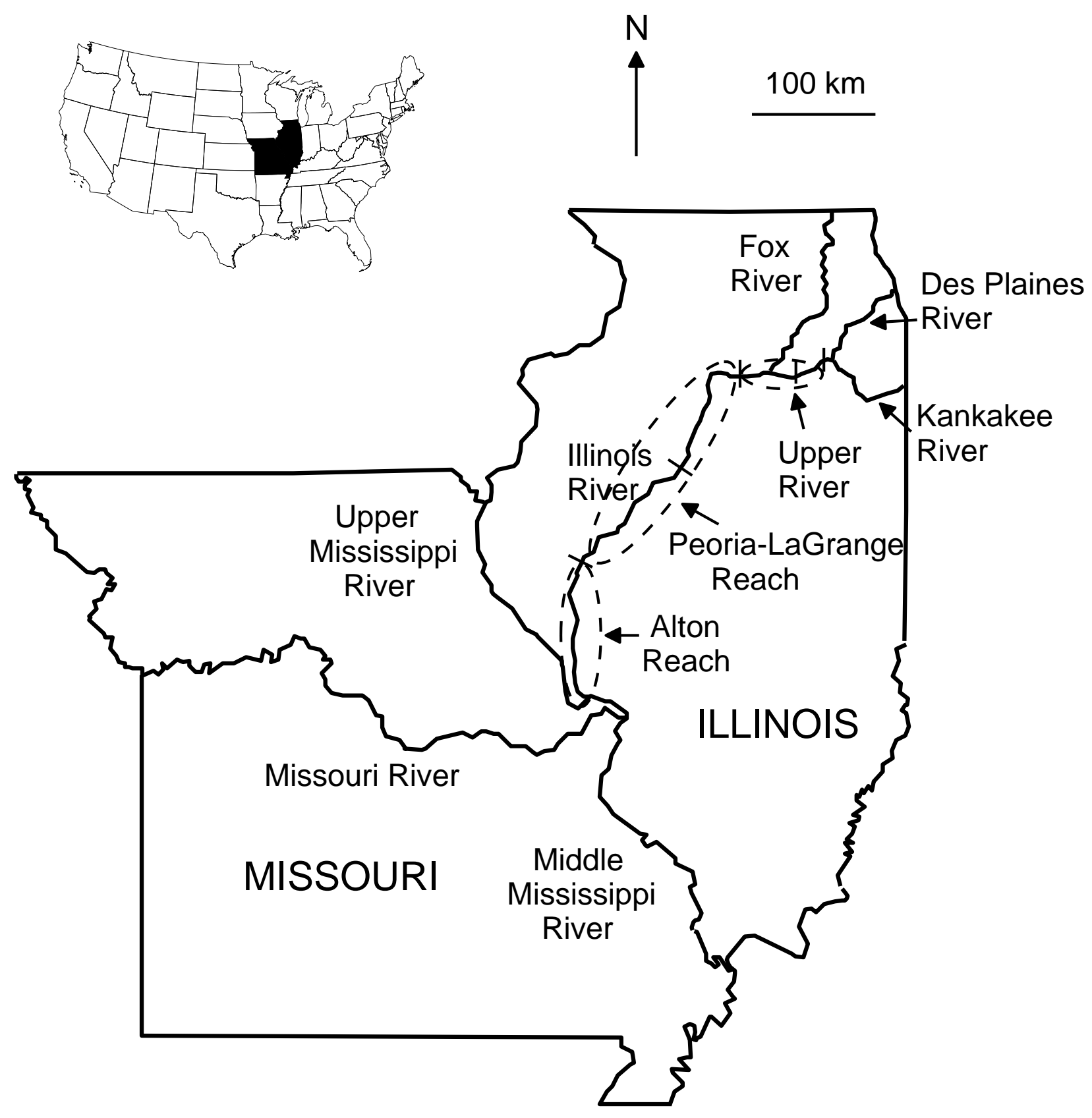


(a)
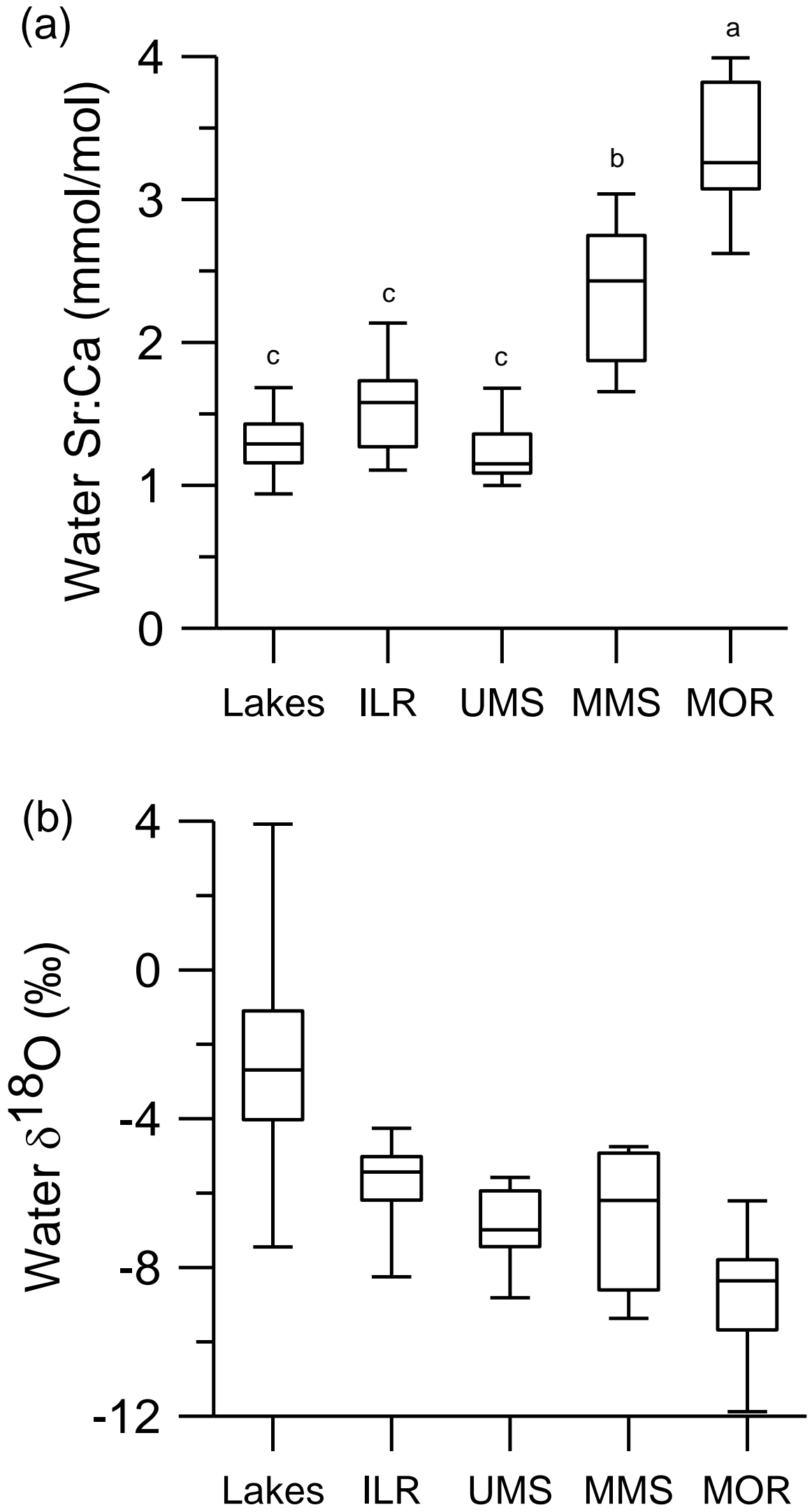


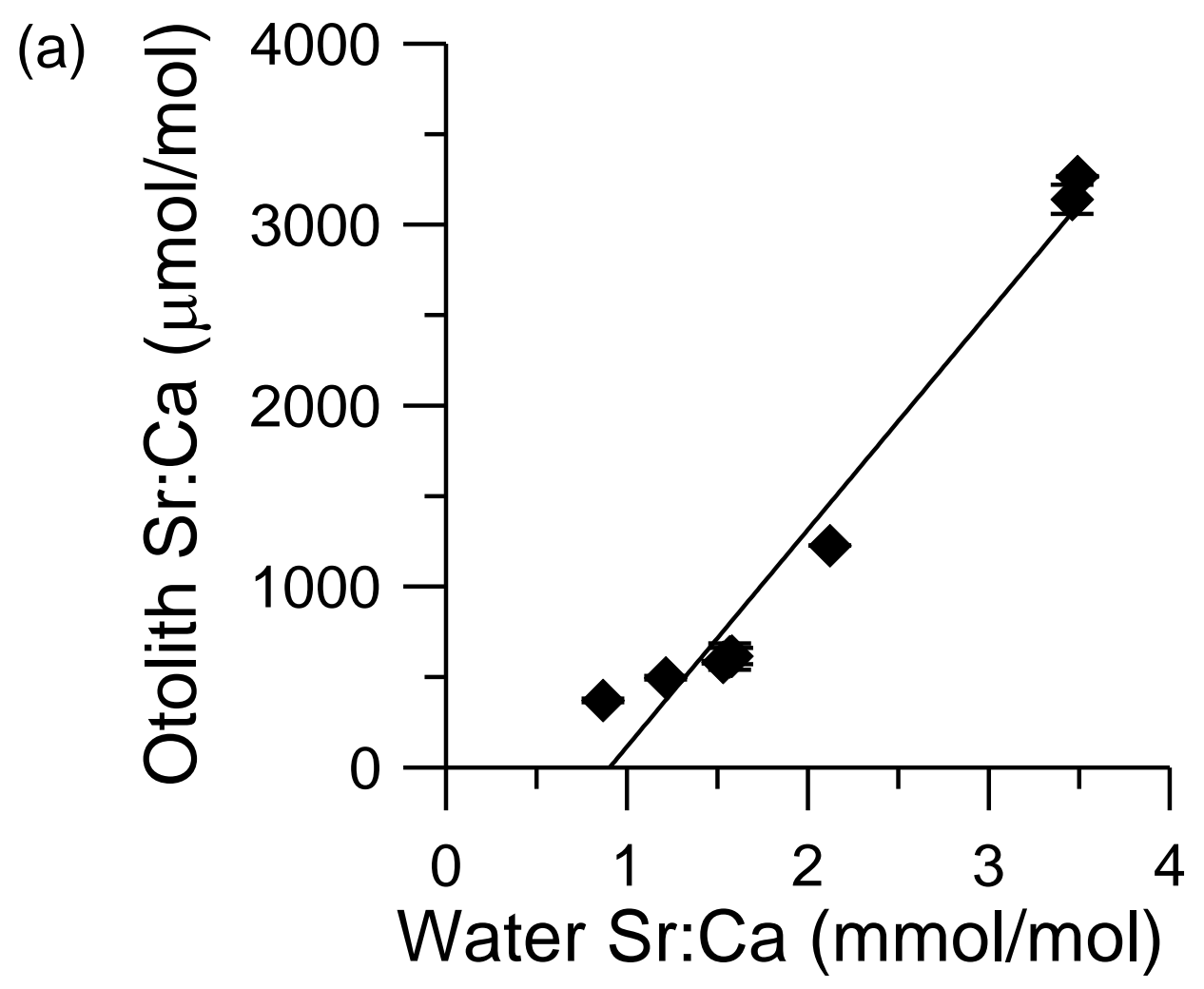

(b)

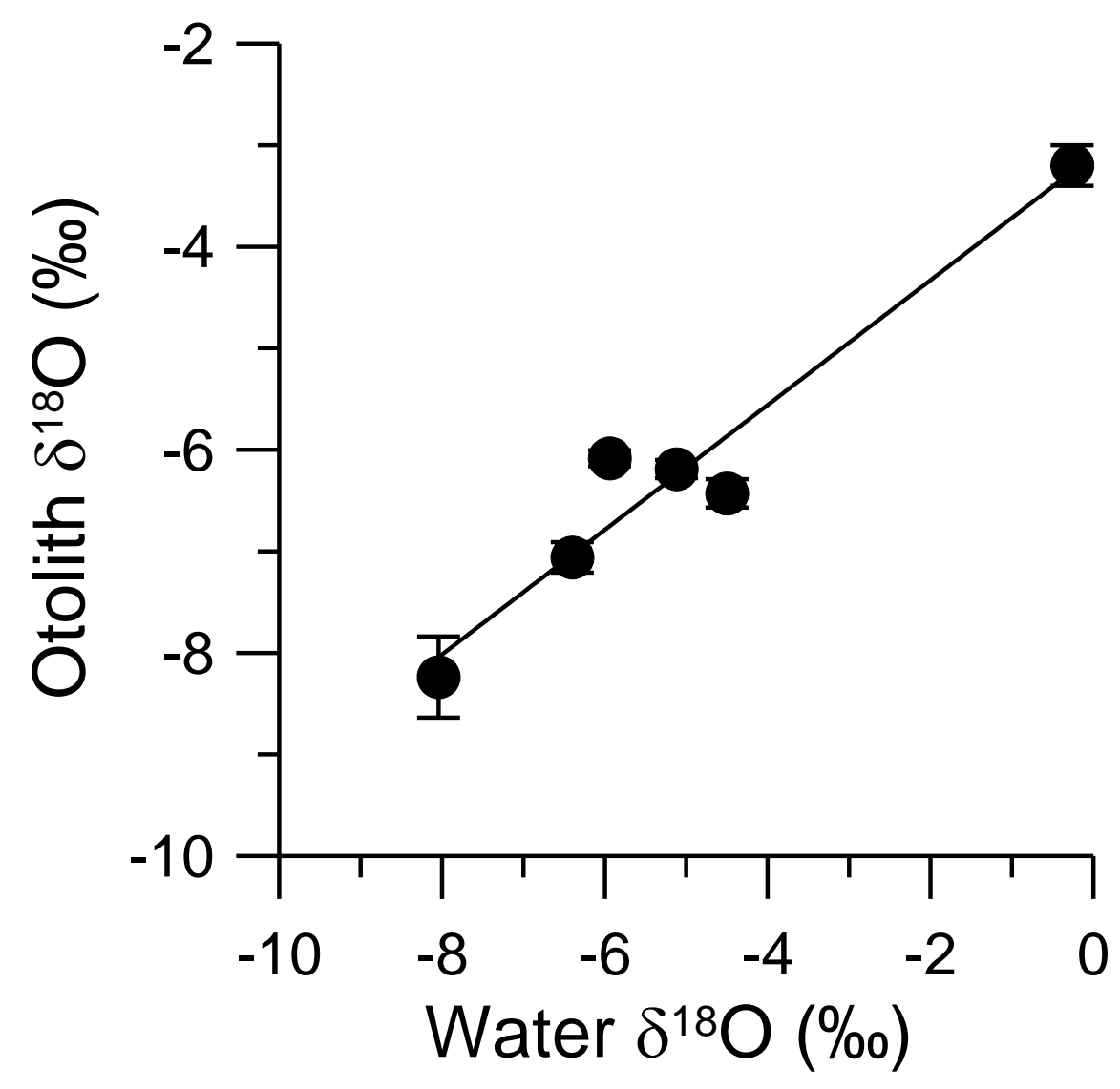


a)

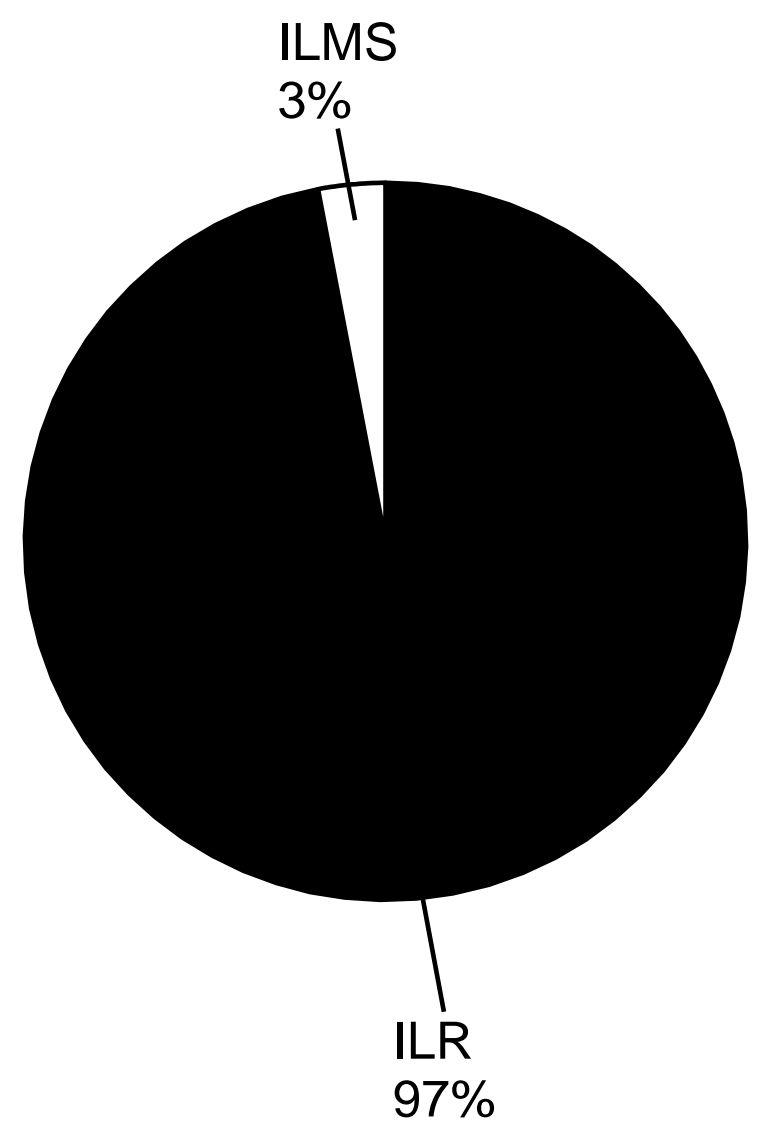

b)

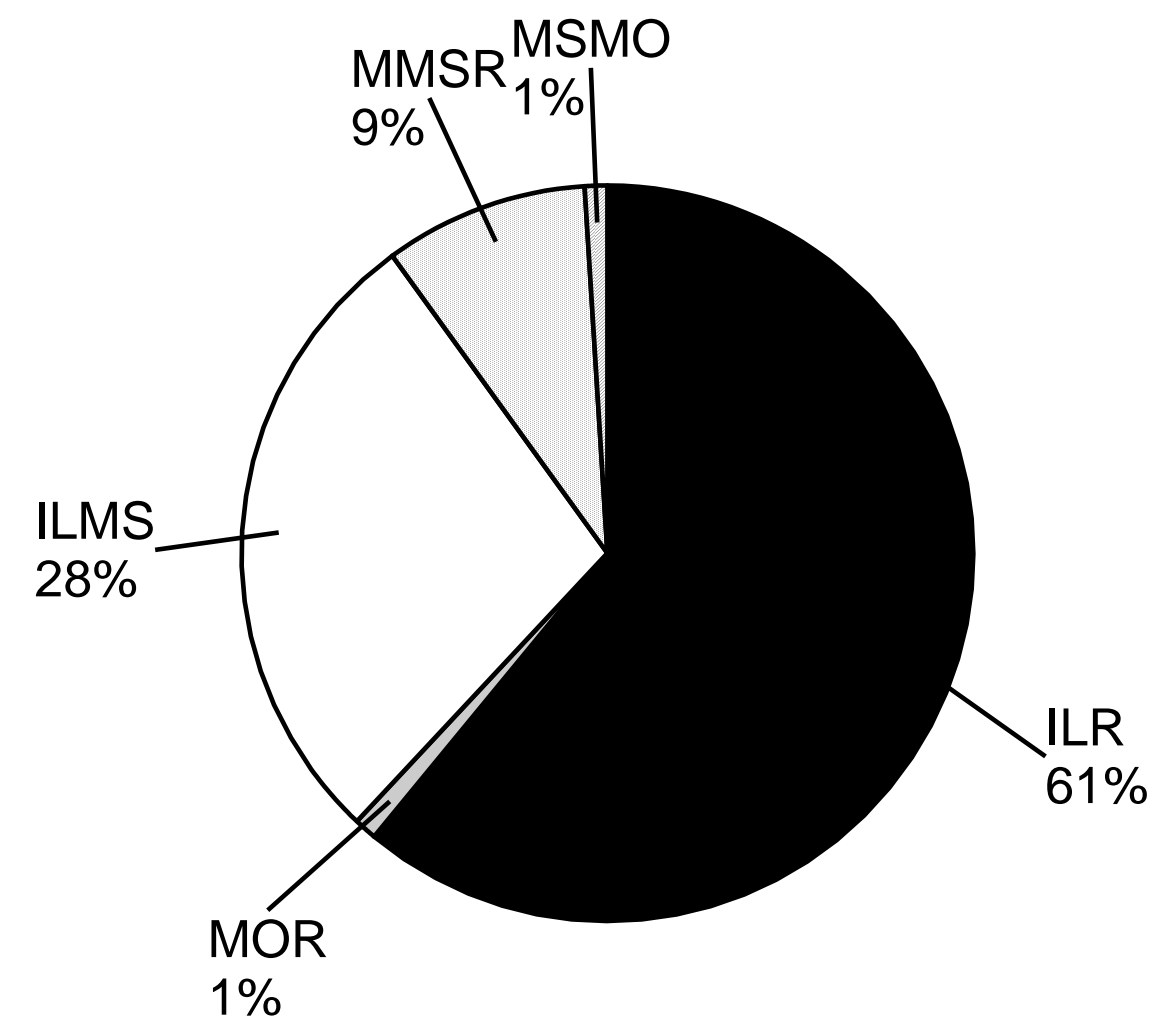


a)

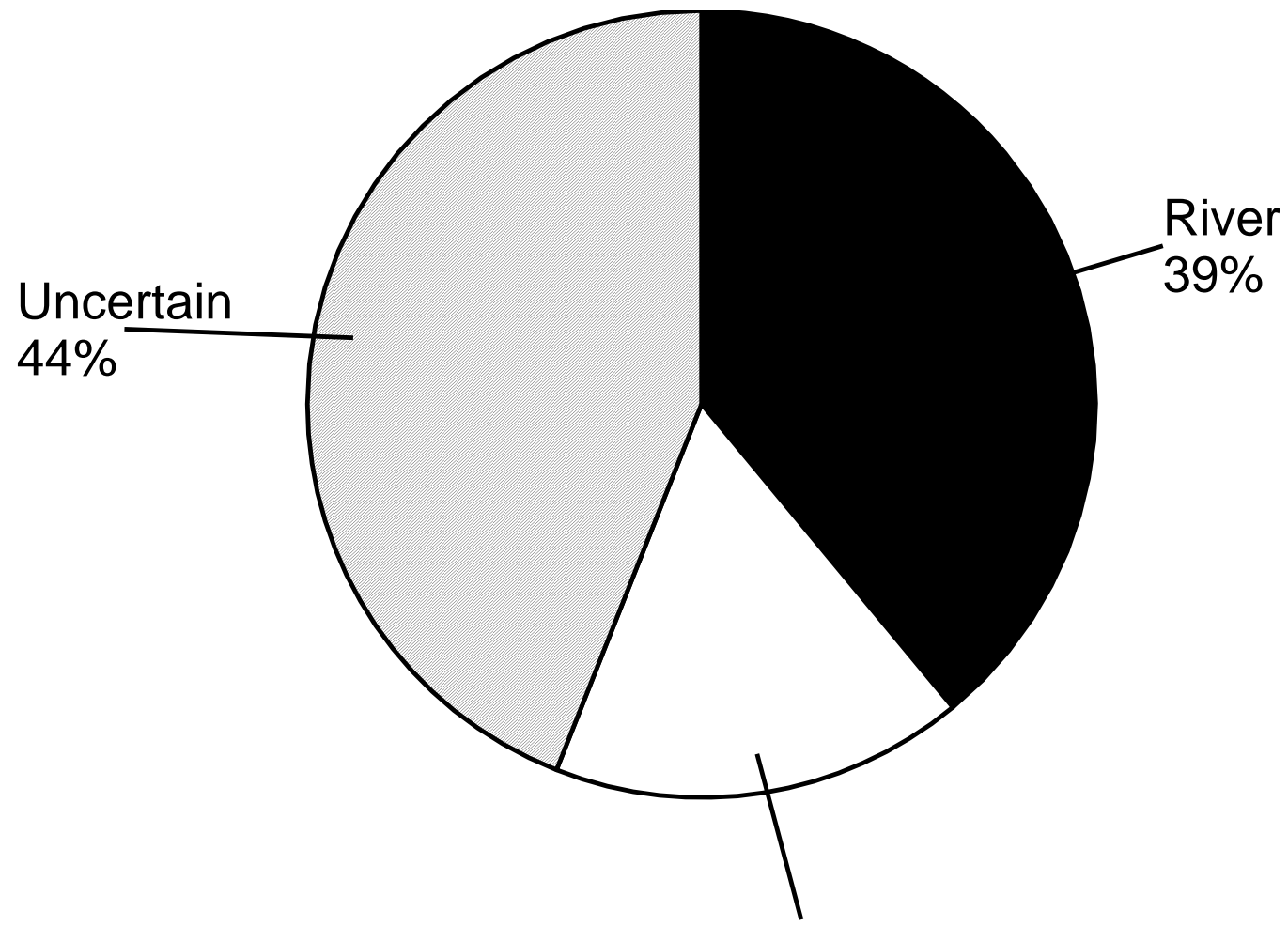

Floodplain Lake

$17 \%$

b)

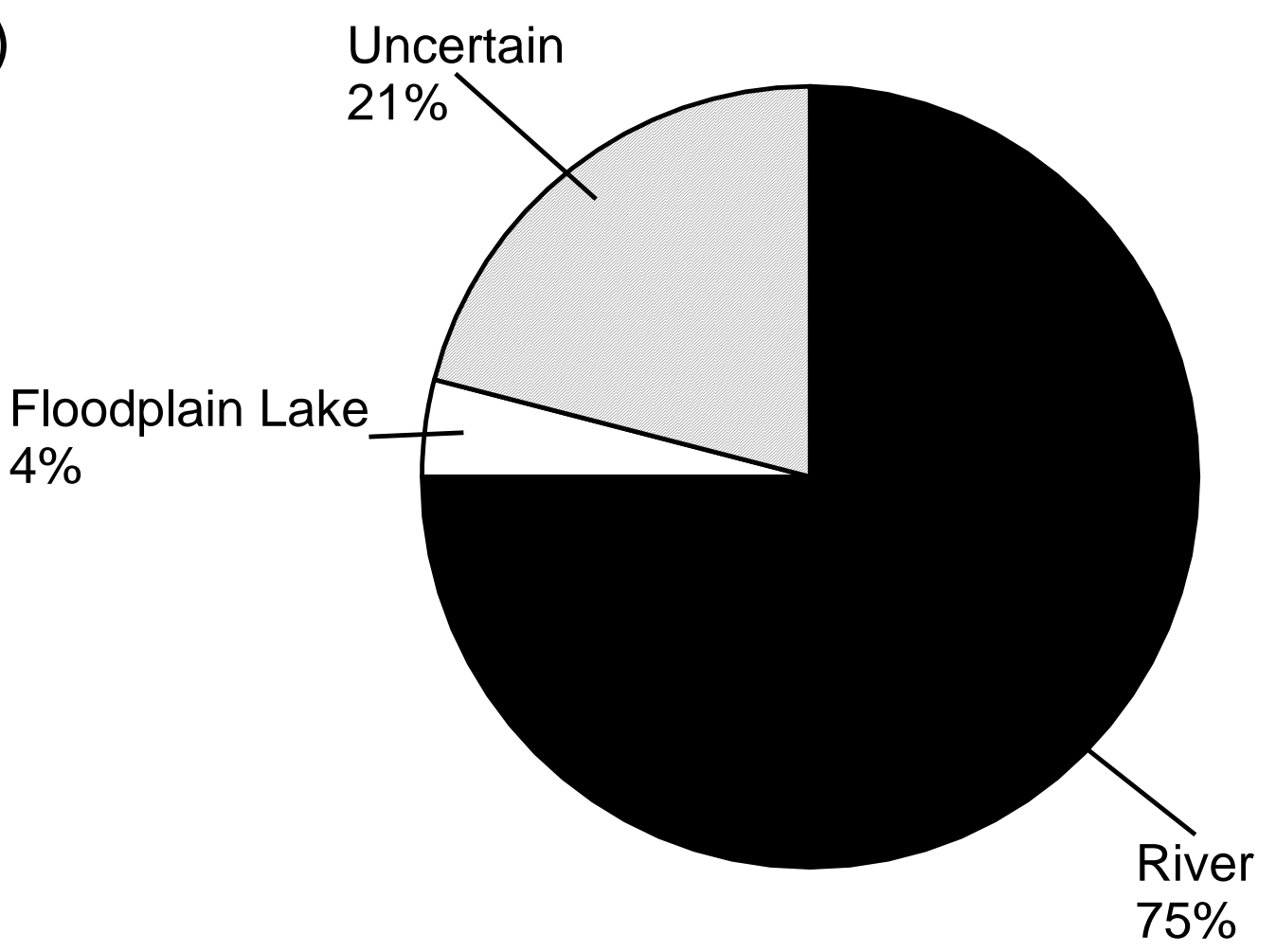




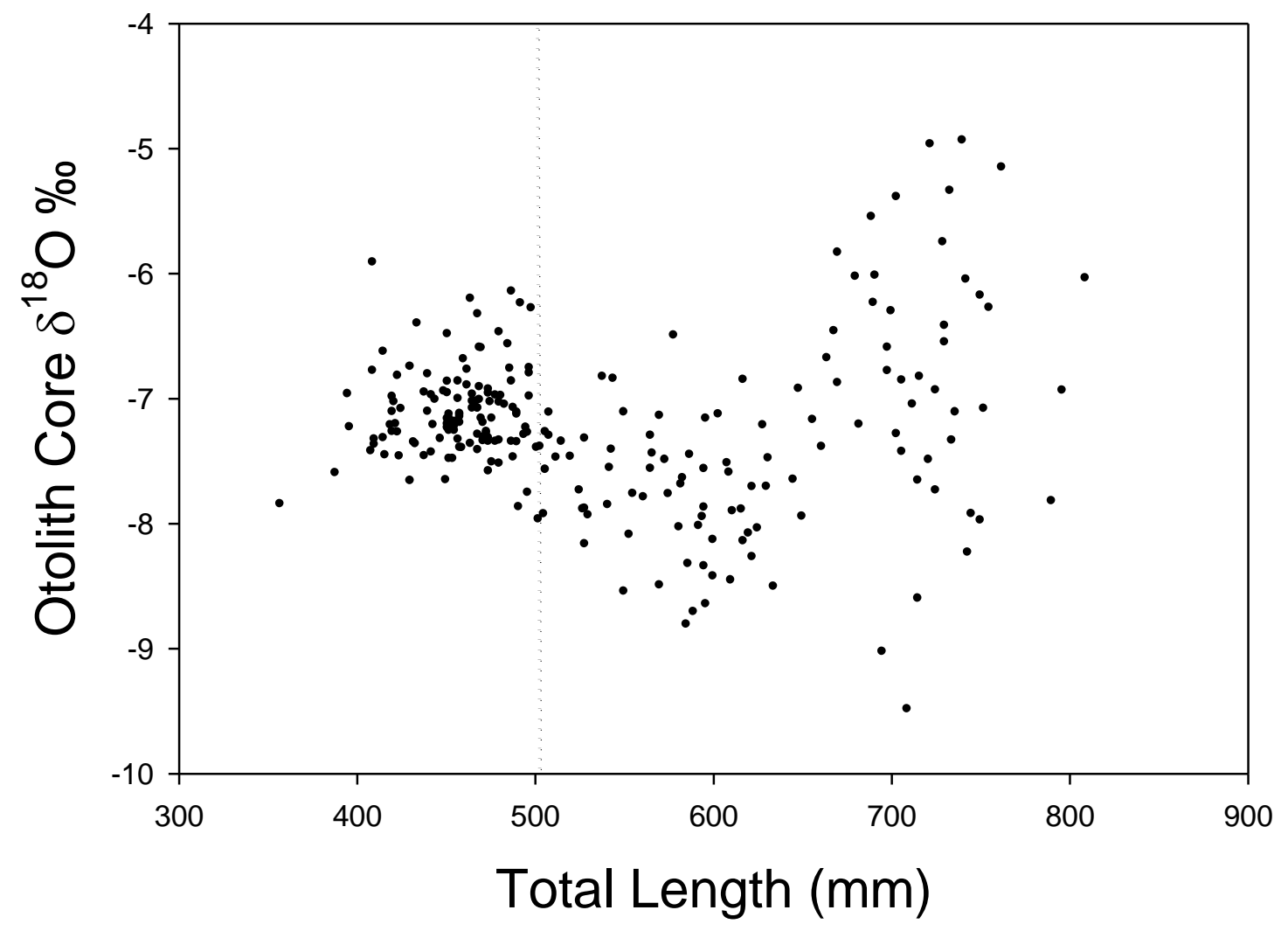

